\title{
Influence of partial soil wetting on water relation parameters of the olive tree
}

Article in Agronomie · November 2003

DOI: 10.1051/agro:2003031

CITATIONS

45

4 authors, including:

A. M.J. Martín-Palomo

Universidad de Sevilla

63 PUBLICATIONS 1,151 CITATIONS

SEE PROFILE

A Ignacio Giron

-8) Spanish National Research Council

65 PUBLICATIONS 1,503 CITATIONS

SEE PROFILE
READS

55

Antonio Diaz-Espejo

Spanish National Research Council

108 PUBLICATIONS 4,880 CITATIONS

SEE PROFILE

Some of the authors of this publication are also working on these related projects:

Project $\quad$ AgroPHYS View project

Assessment of fruit growth response to water stress in a super-high-density olive orchard: monitoring, physiological mechanisms and potential use to schedule irrigation View project 


\title{
Influence of partial soil wetting on water relation parameters of the olive tree
}

\author{
José-Enrique FERNÁNDEZ*, María-José PALOMO, Antonio DíAZ-EsPEJO, Ignacio-Francisco GIRÓN \\ Instituto de Recursos Naturales y Agrobiología (IRNAS, CSIC), Avenida de Reina Mercedes 10, Apartado 1052, 41080 Sevilla, Spain
}

(Received 27 November 2001; accepted 15 January 2003)

\begin{abstract}
A drip versus pond irrigation experiment was carried out with 30-year-old 'Manzanilla' olive trees planted at $7 \mathrm{~m} \times 5 \mathrm{~m}$ in an orchard in Southwest Spain. At the end of the dry season of 1998, we chose two dry-land trees, D1 and D2, and two drip-irrigated trees, I1 and I2. During the experiments, the D1 and I1 trees were pond-irrigated, increasing the soil water content to around field capacity in the whole rootzone. The D2 and I2 trees were drip-irrigated, remaining part of the rootzone in drying soil. The results showed that the ratio between the transpiration of the pond-irrigated D1 tree and that of the drip-irrigated D2 tree (D1/D2 $E_{p}$ ) increased from an average of 0.88 before irrigation to 1.22 fourteen days after the first water supply. For the I trees, I1/I2 $E_{p}$ varied from 0.76 to 1.02 nine days after the I1 tree was pond-irrigated for the first time. Transpiration, therefore, was restricted when using a drip irrigation system which, despite supplying enough water to cover the calculated crop demand, affected a part of the rootzone only. During the drip versus pond irrigation experiment, the recovery of leaf water potential, stomatal conductance and photosynthesis rate was greater and quicker in the pond-irrigated than in the drip-irrigated trees.
\end{abstract}

olive / irrigation / water relation / partial wetting / rewatering / sap flow

Résumé - Influence de l'irrigation partielle du sol sur les paramètres des relations hydriques de l'olivier. Une comparaison de l'irrigation goutte à goutte avec l'irrigation en cuvette a été conduite sur oliviers 'Manzanilla' âgés de 30 ans plantés à $7 \mathrm{~m} \times 5 \mathrm{~m}$ dans un verger du sud-ouest de l'Espagne. À la fin de la saison sèche de 1998, nous avons choisi deux arbres sur sol sec, D1 et D2, et deux arbres sur sol irrigué au goutte à goutte, I1 et I2. Durant les expériences, les arbres D1 et I1 ont été irrigués en cuvette, en augmentant la teneur en eau du sol jusqu'à la capacité au champ dans toute la zone racinaire. Les arbres D2 et I2 ont été irrigués au goutte à goutte, laissant une partie de la zone racinaire dans un sol se desséchant. Les résultats ont montré que le quotient entre la transpiration de l'arbre D1 irrigué en cuvette et celle de l'arbre D2 irrigué au goutte à goutte $\left(\mathrm{D} 1 / \mathrm{D} 2 E_{p}\right)$ a augmenté à partir d'une moyenne de 0,88 avant irrigation jusqu'à 1,22 quatorze jours après le premier apport d'eau. Pour les arbres I, I1/I2 $E_{p}$ a varié entre 0,76 et 1,02 neuf jours après que l'arbre I1 ait été irrigué en cuvette pour la première fois. Par conséquent, la transpiration était réduite quand on utilisait un système d'irrigation au goutte à goutte qui, malgré l'apport d'eau suffisant pour couvrir les besoins potentiels des cultures, a affecté seulement une partie de la zone racinaire. Durant cette comparaison de l'irrigation goutte à goutte et de l'irrigation en cuvette, la récupération de la teneur en eau des feuilles, de la conductance stomatique et du taux de photosynthèse était supérieure et plus rapide pour les arbres irrigués en cuvette que pour ceux irrigués au goutte à goutte.

olivier / irrigation / relation hydrique / arrosage partiel / réhydratation / flux de sève

\section{INTRODUCTION}

In most Mediterranean areas where olive is cultivated the wet season is followed by a long, dry and hot season. Many of the physiological processes of the plant, including shoot and fruit growth, take place mainly in the dry months. Irrigation is, therefore, a compulsory practice in olive orchards where the maximum productivity is to be achieved. Drip irrigation is the most popular system for applying water in olive orchards, mainly due to the fact that most orchards are in arid and semiarid areas where water for irrigation is scarce. The influence of drip irrigation on the root dynamics, root distribution and root activity of the olive tree was studied by Fernández et al. [13, 14]. Later, Moreno et al. [26] used, for the first time in olive, the compensation heat-pulse technique, as described by Green and Clothier [21], to study the water uptake behaviour of the roots. Further studies on root water uptake were published by Fernández et al. [15]. In these studies, however, the influence of the root system on the leaf control of transpiration was not considered. Bongi and Palliotti [3] carried out a split-root experiment with young 'Frantoio' plants in pots, and detected stomatal closure in the plants with a small portion of the root 
system left in dry soil. To our knowledge, this is the only published reference to a possible root-to-leaf signalling mechanism in olive, and whether this phenomenon occurs in mature olive trees under field conditions is unknown. In the field, the root system develops in the whole rootzone during the growing months of the wet season. During the dry season, however, drip and other localised irrigation systems affect a part of the rootzone only, the other part remaining in drying soil. Under these conditions stomatal closure might be induced by the roots left in dry soil, leading to a reduction in gas exchange between the leaves and the surrounding air. This will influence water uptake and, probably, crop productivity. Therefore, any information on this behaviour will be useful to optimise irrigation practices in olive orchards. In fact, the root-to-shoot signalling process is being exploited in agriculture to increase water use efficiency [7]. Another phenomenon related to water use by the olive tree is the recovery of the trees after a lengthy drought period. This is of interest for designing deficit irrigation strategies, widely used in olive orchards [20]. The recovery of water status and gas exchange after rewatering has been studied for several olive varieties $[11,16,27]$ but, to our knowledge, the influence of wetting the whole rootzone, or just part of it, on the recovery, has not been studied yet.

The main objective of this work was to investigate whether drip irrigation - as compared with pond irrigation in which the whole rootzone is wetted - limits water consumption in mature 'Manzanilla' olive trees under field conditions. In addition, it was investigated whether the type of irrigation influences the recovery of leaf water potential and gas exchange following rewatering after a long period of drought.

\section{MATERIALS AND METHODS}

\subsection{Experimental orchard}

The experiments were conducted in an olive orchard of $\mathrm{La}$ Hampa, the experimental farm of the Instituto de Recursos Naturales y Agrobiología (IRNAS, CSIC), close to Coria del Río, Seville (latitude $37^{\circ} 17^{\prime} \mathrm{N}$, longitude $6^{\circ} 3$ ' W, altitude $30 \mathrm{~m}$ ). The trees were 30-year-old 'Manzanilla de Sevilla' (referred to here as 'Manzanilla') olive trees (Olea europaea L.) at $7 \mathrm{~m} \times$ $5 \mathrm{~m}$ spacing. The soil of the orchard is a sandy loam (Xerochrept) of variable depth. A hard limy sandstone pan impedes the penetration of both roots and water at a depth which varies within the orchard from about 0.9 to $2.0 \mathrm{~m}$. Soil texture is quite homogeneous, both vertically and horizontally. From the surface to the hardpan, the average textural values are $14.8 \%$ clay, $7.0 \%$ silt, $4.7 \%$ fine sand and $73.5 \%$ coarse sand. The water table remains far below the maximum depth of the root system [18]. The volumetric soil water content $\left(\theta, \mathrm{m}^{3} \cdot \mathrm{m}^{-3}\right)$ measured in the laboratory was $0.33 \mathrm{~m}^{3} \cdot \mathrm{m}^{-3}$ in saturated soil samples and $0.10 \mathrm{~m}^{3} \cdot \mathrm{m}^{-3}$ at a soil matric potential of $-1.5 \mathrm{MPa}$. In the field, the values of $\theta$ measured close to the drippers a few hours after irrigation were rarely greater than $0.20 \mathrm{~m}^{3} \cdot \mathrm{m}^{-3}$. Next to the experimental orchard there is an automatic weather station where thirty-minute averages of wind speed and direction, rainfall, air temperature and humidity, global solar radiation and photosynthetically active radiation are continuously recorded. The climate of the area is typically Mediterranean, being dry and hot from May to October and mild and rainy for the rest of the year. For the last 25 years, the average rainfall and reference evapotranspiration $\left(E T_{o}\right)$ registered in the orchard have been $484 \mathrm{~mm}$ and $1442 \mathrm{~mm}$, respectively. The crop management practices carried out in the orchard are similar to those of representative commercial orchards in the area. One part of the orchard has always been under dry-farming conditions (D trees), whereas the other has always been drip irrigated during the dry seasons (I trees). In the last five years a single drip line per tree row has been used, placed on the soil surface and with five $3 \mathrm{~L} \cdot \mathrm{h}^{-1}$ drippers per tree spaced $1 \mathrm{~m}$ apart. Daily irrigation was applied to the I trees during the dry seasons, to replace the crop water demand $\left(E T_{c}, \mathrm{~mm}\right)$. The irrigation needs were calculated every week, using the equation

$$
E T_{c}=K_{c} K_{r} E T_{o} .
$$

The reference evapotranspiration was calculated by the FAO-Penman equation [9], which Mantovani et al. [23] validated as the most appropriate for the area. The values of the crop $\left(K_{c}\right)$ and reduction $\left(K_{r}\right)$ coefficients were those recommended by Fernández et al. [16] and Fernández and Moreno [12] for the orchard conditions.

\subsection{Irrigation experiment}

In 1998, the experimental year, the dry season began in March. The I trees were irrigated daily from March 24 until the end of September, when the first autumn rains were recorded. Once the wetted bulbs - the soil volumes under the drippers affected by irrigation - were well established, the diameter of the ground surface wetted by each dripper was rarely greater than $1 \mathrm{~m}$, which accounts for a maximum wetted ground surface of about $4 \mathrm{~m}^{2}$ per tree. A rough estimation from soil sampling around the wetted bulbs allowed us to establish the average wetted soil volume per tree as about $7 \mathrm{~m}^{3}$, being rarely greater than $10 \mathrm{~m}^{3}$. This accounts for 20 to $30 \%$ of the total soil volume of each tree. This, together with the data on root distribution obtained by Fernández et al. [13] in the same orchard, allows us to assume that just a part of the root system of the drip-irrigated I trees was affected by irrigation; the other part remained in drying soil throughout the dry season. In the nonirrigated D trees, the whole root system was in drying soil throughout the dry season.

At the end of August 1998 we started what we will call the drip versus pond irrigation experiment. We chose two dryland trees, D1 and D2, and two drip-irrigated trees, I1 and I2. All the trees were similar in size, about $4.5 \mathrm{~m}$ tall and with a crown diameter of about $5.0 \mathrm{~m}$. They had a single trunk of about $0.2 \mathrm{~m}$ diameter with two main branches at about 1.2 $1.6 \mathrm{~m}$ above ground. The previous year Palomo [28] had estimated that the maximum leaf area of the trees ranged from about 61 to $64 \mathrm{~m}^{2}$. An earthen dyke of $13 \mathrm{~m} \times 9 \mathrm{~m}$ was built around the D1 and I1 trees, for pond irrigation. Enough water was added to the D1 and I1 trees (Tab. I) to increase the soil water content to around field capacity in the whole rootzone (Tab. II). The D2 tree was drip irrigated from August 25, by a drip line with five $6 \mathrm{~L} \cdot \mathrm{h}^{-1}$ emitters spaced $1 \mathrm{~m}$ apart (Tab. I). The irrigation doses applied to this tree were more than double the required amount of water to replace the $E T_{c}$ calculated with equation (1), which averaged $73 \mathrm{~L} \cdot \mathrm{d}^{-1}$ for the period between August 25 and September 11. Thus, in a short period of time 
Table I. Water supplied to the experimental trees at the end of the summer of 1998, in the drip versus pond irrigation experiment. The dates of the irrigation events and the irrigation types are specified. Prior to the irrigation events detailed in this table, the I1 and I2 trees were irrigated daily from the beginning of the dry season, on March 24, while the D1 and D2 trees were under dry-farming conditions. Details are given in the text. DOY = day of year. GMT = Greenwich Mean Time.

\begin{tabular}{|c|c|c|c|c|}
\hline Tree & Date & DOY & Water supplied & Irrigation type \\
\hline \multirow[t]{5}{*}{ D1 } & August 25 & 237 & $142 \mathrm{~mm}^{(*)}$ & Pond \\
\hline & " 27 & 239 & $62 "$ & " \\
\hline & " 31 & 243 & $78 "$ & $"$ \\
\hline & September 4 & 247 & $87 \quad$ & $"$ \\
\hline & " 7 & 250 & $72 "$ & $"$ \\
\hline D2 & $\begin{array}{l}\text { From August } 25 \\
\text { to September } 11\end{array}$ & $237-254$ & $190 \mathrm{~L} \cdot \mathrm{d}^{-1}\left(^{*}\right)$ & Daily drip \\
\hline \multirow[t]{4}{*}{ I1 } & September 3 & 246 & $151 \mathrm{~mm}^{(*)}$ & Pond \\
\hline & " 7 & 250 & $78 "$ & " \\
\hline & $\begin{array}{l}\text { From August } 31 \\
\text { to September } 6\end{array}$ & $243-249$ & $82 \mathrm{~L} \cdot \mathrm{d}^{-1}$ & Daily drip \\
\hline & $\begin{array}{c}\text { From September } 7 \\
\text { to September } 13\end{array}$ & $250-256$ & $72 \mathrm{~L} \cdot \mathrm{d}^{-1}$ & Daily drip \\
\hline \multirow[t]{2}{*}{$\mathrm{I} 2$} & $\begin{array}{c}\text { From August } 31 \\
\text { to September } 6\end{array}$ & $243-249$ & $82 \mathrm{~L} \cdot \mathrm{d}^{-1}$ & Daily drip \\
\hline & $\begin{array}{c}\text { From September } 7 \\
\text { to September } 13\end{array}$ & $250-256$ & $72 \mathrm{~L} \cdot \mathrm{d}^{-1}$ & Daily drip \\
\hline
\end{tabular}

${ }^{(*)}$ The irrigation events of August 25 and September 3 began at about 13.00 GMT.

Table II. Average volumetric soil water content $(\theta)$ measured around the experimental trees before and during the drip versus pond irrigation experiment. The shown data correspond to the soil volumes affected by irrigation. The average $\theta$ values in the soil volumes non-affected by irrigation were $0.11 \mathrm{~m}^{3} \cdot \mathrm{m}^{-3}$ for the $\mathrm{D}$ trees and $0.12 \mathrm{~m}^{3} \cdot \mathrm{m}^{-3}$ for the I trees, remaining about constant during the experiment. Details on the experimental trees and the measurements are given in the text. DOY = day of year.

\begin{tabular}{lllll}
\hline \multicolumn{5}{c}{$\theta\left(\mathrm{m}^{3} \cdot \mathrm{m}^{-3}\right)$} \\
\hline DOY & D1 & D2 & I1 & I2 \\
237 & 0.14 & 0.10 & & \\
238 & 0.18 & 0.12 & & \\
239 & 0.18 & 0.13 & & \\
240 & 0.20 & 0.14 & & \\
243 & 0.19 & 0.15 & & \\
245 & 0.19 & 0.16 & 0.18 & 0.20 \\
246 & & & 0.20 & 0.21 \\
250 & 0.19 & 0.17 & 0.19 & 0.20 \\
254 & 0.19 & 0.17 & 0.19 & 0.20 \\
\hline
\end{tabular}

the wetted bulbs were well established in that previously nonirrigated D2 tree (Tab. II). The I2 tree was irrigated from March 24, with daily drip irrigation to replace $E T_{c}$, as explained above. Therefore, at the beginning of September we had the D1 tree with the whole rootzone affected by pond irrigation and the D2 tree with just part of the rootzone affected by drip irrigation. This pair of trees was previously under dryfarming conditions. We also had a second pair of trees, the I1 tree with the whole rootzone affected by pond irrigation and the I 2 tree with just part of the rootzone affected by drip irrigation. This pair of trees was drip irrigated from the beginning of the dry season.

\subsection{Sap flow measurements}

We used the compensation heat-pulse method, as described by Green and Clothier [21], for estimating sap flows in the four experimental trees. Details on the calibration and testing of the technique for the olive tree, as well as on data analysis, are given in Fernández et al. [17]. On August 20 three sets of heat-pulse probes were installed at three equal spacings around the azimuth of the D1 and D2 tree trunks. On August 31 three sets of probes were also installed in the I1 and I 2 trees, following the same criteria as in the D trees. In all cases the probes were installed in places free of gnarled knots and scars. Each probe measured the sap velocity at 5, 12, 22 and $35 \mathrm{~mm}$ below the cambium. Measurements were made every half hour, for the entire experimental period. The data were collected by a Campbell CR10X data logger (Campell Scientific Inc., USA). The transpiration of each tree $\left(E_{p}, \mathrm{~L} \cdot \mathrm{d}^{-1}\right)$ was estimated from the sap flow records, calculating the sap flux densities $\left(J, \mathrm{~mm} \cdot \mathrm{h}^{-1}\right)$ as described by Fernández et al. [17].

Despite applying the described methodology with rigour and care, significant differences between the actual transpiration values and the calculated $E_{p}$ values might not be avoided. This is due to the high variability of the cross-sectional conductive area in the trunk of mature olive trees, among other factors described by Fernández et al. [17]. In that work, in fact, it is shown that individual $E_{p}$ data from mature olive trees are influenced by probe location. Consequently, and for the purpose of our study, analysing the ratio between the two pair of trees (D1/D2 $E_{p}$ and I1/I2 $E_{p}$ ) was more advantageous than considering individual $E_{p}$ data. This allowed us to detect the influence of wetting the whole rootzone, or just part of it, on transpiration, at the same time as avoiding making mistakes caused by the mentioned variability. 


\subsection{Leaf water status and gas exchange measurements}

Leaf water potential ( $\left.\Psi_{l}, \mathrm{MPa}\right)$ was measured in the $\mathrm{D}$ and in the I trees once per month, from the beginning of the dry season to the beginning of the drip versus pond irrigation experiment. Measurements were carried out just before dawn $\left(\Psi_{p d}\right)$ and at around 10.00 GMT $\left(\Psi_{10}\right)$ when the leaves showed the minimum daily values of $\Psi_{l}[16]$. One sunlit and healthy leaf of the current year was sampled per tree, in six trees of both the D and I treatments. We measured the xylem pressure potential at the petiole with a pressure chamber (Soilmoisture Equipment Corp., Santa Bárbara, California, USA), and assumed it to be equal to the leaf water potential. During the drip versus pond irrigation experiment, measurements of $\Psi_{p d}$ and $\Psi_{10}$ were made nearly every day, in six leaves per tree, in the four experimental trees. Immediately after measuring $\Psi_{10}$, measurements of stomatal conductance to $\mathrm{H}_{2} \mathrm{O}\left(g_{s}\right.$, $\left.\mathrm{mol} \cdot \mathrm{m}^{-2} \cdot \mathrm{s}^{-1}\right)$ and the net photosynthesis rate $\left(P_{N}, \mu \mathrm{mol} \cdot \mathrm{m}^{-2} \cdot \mathrm{s}^{-1}\right)$ were carried out with a portable photosynthesis system (LI6400, LI-COR, Lincoln, Nebraska, USA). These two variables were measured in 10 leaves per tree of the same type as described above, in each one of the four experimental trees. The measurements were made at around 10.30 GMT, when the daily maximum values of $g_{s}$ were registered.

\subsection{Soil water measurements}

Measurements of $\theta$ were made every $15-20 \mathrm{~d}$ in three D and three I trees from the beginning of the dry season to the beginning of the drip versus pond irrigation experiment. We used a neutron probe (Troxler 3300, Research Triangle Park, North Carolina, USA) for measuring $\theta$ every $0.1 \mathrm{~m}$, from $0.3 \mathrm{~m}$ down to the maximum depth explored by the roots. In the top soil layers $\theta$ was measured by gravimetry. During the drip versus pond irrigation experiment, measurements of $\theta$ were made nearly every day. The access tubes for the neutron probe were installed $0.5,1.5,2.5$ and $3.5 \mathrm{~m}$ away from the trunks of the D1 and I1 trees, and 1.5 and $2.5 \mathrm{~m}$ away from the D2 and I2 trees. The access tubes went to the depth of the hardpan, $2 \mathrm{~m}$ in the D1 tree, $1.7 \mathrm{~m}$ in the $\mathrm{D} 2$ tree and $1 \mathrm{~m}$ in both the I1 and I2 trees.

\section{RESULTS}

\subsection{Water status in the orchard throughout the dry season}

Figure 1 shows the time course of $E T_{o}, \theta, \Psi_{p d}$ and $\Psi_{10}$ recorded from the beginning of the dry season to the beginning of the drip versus pond irrigation experiment, for both the D and I trees. The daily $E T_{o}$ (Fig. 1a) was over $8 \mathrm{~mm}$ often during the season, reaching a maximum value of $10 \mathrm{~mm}$ on August 3, day of year (DOY) 215. This illustrates the high atmospheric demand normally found during the dry and hot summer months in the area. Figure $1 \mathrm{~b}$ shows that $\theta$ remained at about $0.19 \mathrm{~m}^{3} \cdot \mathrm{m}^{-3}$ in the wetted bulbs of the drip-irrigated I trees. The fact that $\theta$ remained constant and close to field capacity throughout the dry season indicates that the water supplied to the I trees was enough to cover the crop water demand. As

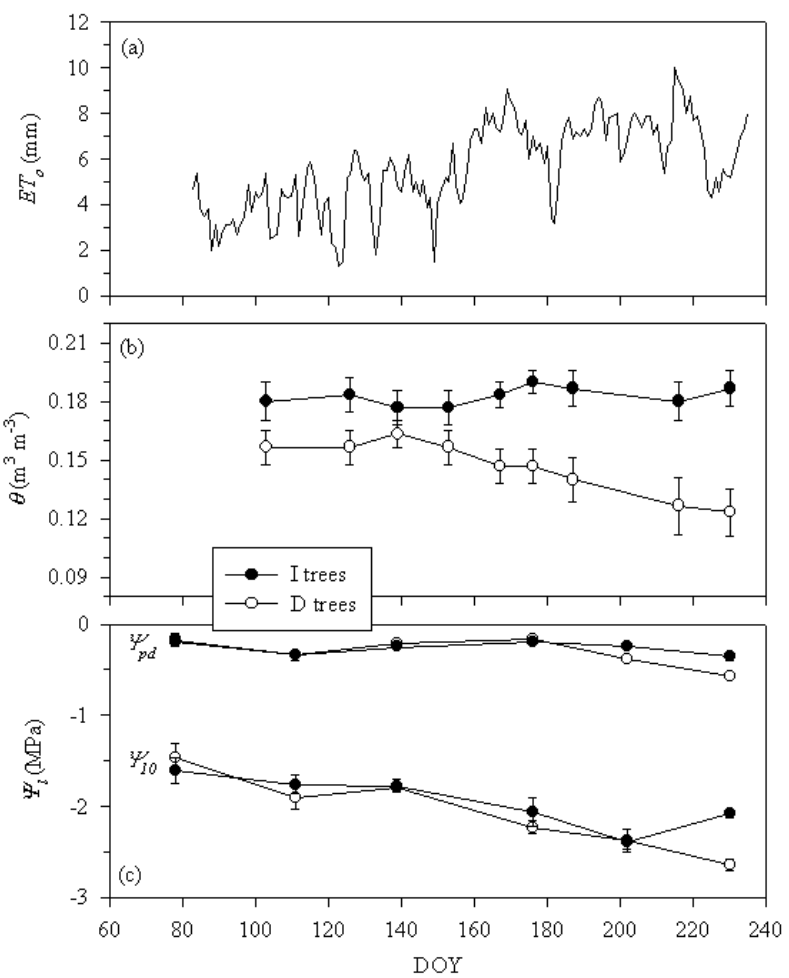

Figure 1. Time course of reference evapotranspiration $\left(E T_{o}\right)$, volumetric soil water content $(\theta)$ and leaf water potential $\left(\Psi_{l}\right)$ measured at predawn $\left(\Psi_{p d}\right)$ and at about 10.00 GMT $\left(\Psi_{10}\right)$, when the daily minimum values were recorded. Measurements were made throughout the dry season of 1998, in the non-irrigated (D) and dripirrigated (I) trees of the experimental orchard. Irrigation of the I trees began on March 24, DOY 83. For the D1 and I1 trees, each $\theta$ point represents the average of the three soil water profiles measured through the three access tubes closest to the trunk. For the D2 and I2 trees the $\theta$ points are averages of the two measured soil water profiles. For $\Psi_{l}$ each point represents the average of six values. Vertical bars indicate twice the standard error. Details on the measurements and on the irrigation treatments are given in the text. DOY = day of year. GMT = Greenwich Mean Time.

expected, $\theta$ around the $\mathrm{D}$ trees decreased throughout the dry season, reaching a minimum average value of $0.12 \mathrm{~m}^{3} \cdot \mathrm{m}^{-3}$ on DOY 230. Significant differences in leaf water status between the $\mathrm{D}$ and the I trees appeared quite late in the season (Fig. 1c). Although data on relative water content and osmotic potential are also required to assess the leaf water status, data on $\Psi_{l}$ (Fig. 1c) show clear differences between the D and I trees just before the beginning of the drip versus pond irrigation experiment $(P<0.001)$. Thus, on DOY 230, the last date shown in Figure 1c, the average $\Psi_{p d}$ was $-0.35 \mathrm{MPa}$ in the I trees and $-0.57 \mathrm{MPa}$ in the D trees. The average $\Psi_{10}$ values recorded on that day were $-2.08 \mathrm{MPa}$ for the I trees and -2.64 MPa for the $\mathrm{D}$ trees.

\subsection{Tree transpiration during the drip versus pond irrigation experiment}

The ratio of $E_{p}$ between the D1 and D2 trees (D1/D2 $E_{p}$ ) calculated from the sap flow measurements before and during 

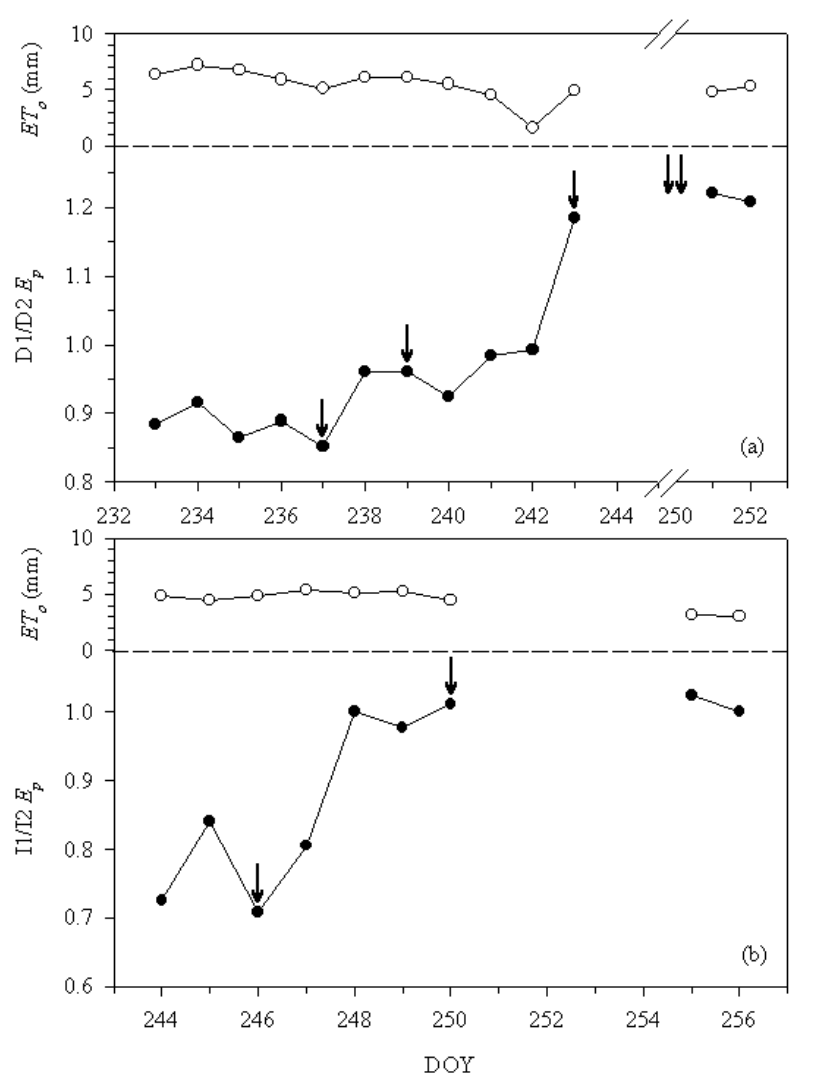

Figure 2. Relative total daily transpiration between (a) the trees D1 and D2 (D1/D2 $\left.E_{p}\right)$ and (b) the trees I1 and I2 (I1/I2 $\left.E_{p}\right)$, calculated from sap flow measurements in the trunk of the trees before and during the drip versus pond irrigation experiment. The daily values of reference evapotranspiration $\left(E T_{o}\right)$ are also shown. The arrows represent the irrigation events detailed in Table I. The D1 and I1 trees were pond irrigated, while the D2 and I2 trees were drip irrigated. Further details on both treatments are given in the text. DOY = day of year.

the drip versus pond irrigation experiment are shown in Figure 2a. On the days before the beginning of the experiment the daily D1/D2 $E_{p}$ rate was quite stable, with an average value of 0.89 . On DOY 238, just one day after the beginning of the experiment, D1/D2 $E_{p}$ was 0.96 , increasing quickly on the subsequent days to a maximum of 1.22 on DOY 251. Thus, two weeks after the beginning of the experiment the increase in $E_{p}$ was $37 \%$ greater on the pond-irrigated D1 tree than on the drip-irrigated D2 tree. A similar trend in relative transpiration was observed in the I trees (Fig. 2b). In fact, prior to the beginning of the drip versus pond irrigation experiment the average I1/I2 $E_{p}$ was 0.78 , while at the end of the experiment, on DOY 255, it was 1.02 . This means that the increase in $E_{p}$ nine days after the beginning of the experiment was $31 \%$ greater for the pond-irrigated I1 tree than for the drip-irrigated $\mathrm{I} 2$ tree. Figures $2 \mathrm{a}$ and $2 \mathrm{~b}$ also show the $E T_{o}$ values calculated for the measuring days.

Table II shows slightly higher $\theta$ values on DOY 250 in the D1 tree than in the D2 tree. The differences, however, were

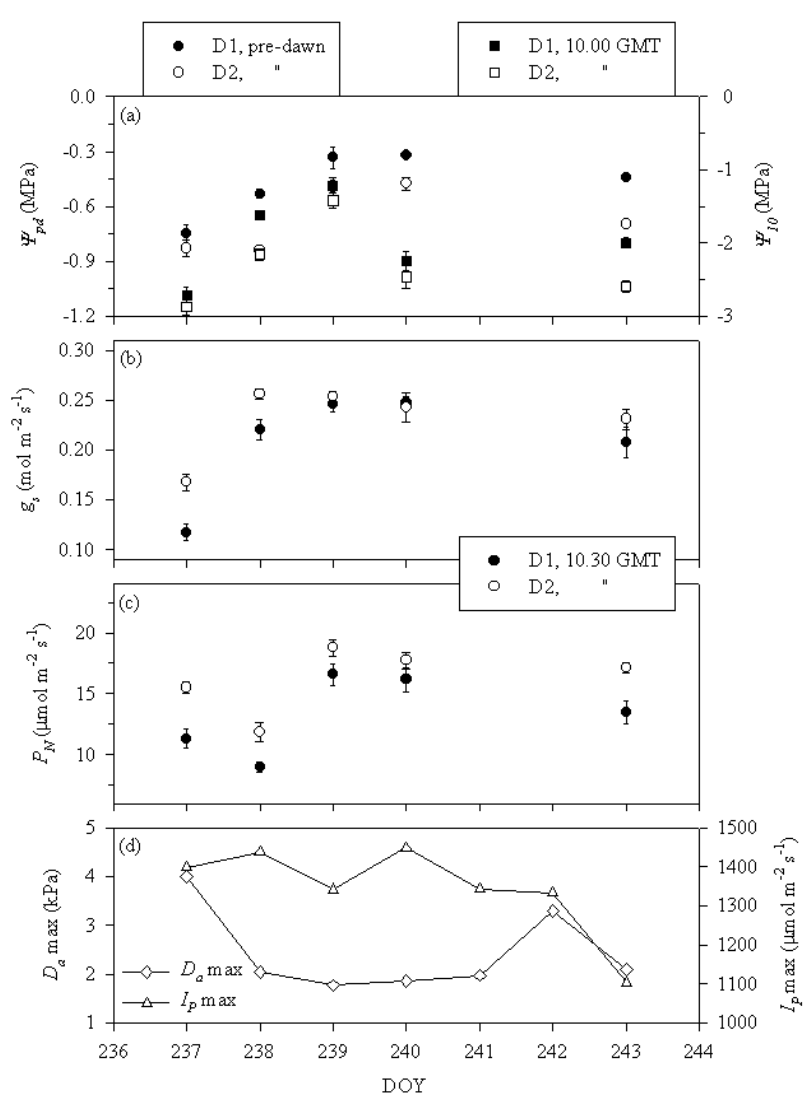

Figure 3. Leaf water status and gas exchange measurements measured in current year leaves of the $\mathrm{D}$ trees before and during the drip versus pond irrigation experiment. Figure 3 a shows the values of leaf water potential at predawn $\left(\Psi_{p d}\right)$ and at 10.00 GMT $\left(\Psi_{10}\right)$; each point represents the average of six values. Figure $3 \mathrm{~b}$ and $3 \mathrm{c}$ show the values of stomatal conductance to $\mathrm{H}_{2} \mathrm{O}\left(g_{S}\right)$ and net photosynthesis $\left(P_{N}\right)$, respectively, measured at $10.30 \mathrm{GMT}$; each point represents the average of 10 values. Vertical bars indicate twice the standard error. The D1 tree was pond irrigated, while the D2 tree was drip irrigated. Further details on both treatments are given in the text. Figure $3 \mathrm{~d}$ shows the daily maximum values of vapour pressure deficit of the air $\left(D_{a}\right.$ max $)$ and photon flux density $\left(I_{P} \max \right)$ recorded on the measurement days. DOY $=$ day of year. GMT $=$ Greenwich Mean Time.

due to the water stored in deep soil layers only. In fact, below $1 \mathrm{~m}$ depth the average $\theta$ value measured on DOY 250 was $0.21 \mathrm{~m}^{3} \cdot \mathrm{m}^{-3}$ in the D1 tree and $0.14 \mathrm{~m}^{3} \cdot \mathrm{m}^{-3}$ in the D2 tree. In the layer of $0-1 \mathrm{~m}$ depth, however, the average $\theta$ value was $0.18 \mathrm{~m}^{3} \cdot \mathrm{m}^{-3}$ for both trees, indicating conditions close to field capacity. Values of $\theta$ around those of field capacity were also recorded in the wetted bulbs of the I trees (Tab. II).

\subsection{Leaf water status and gas exchange during the drip versus pond irrigation experiment}

The recovery of $\Psi_{p d}$ after irrigation began earlier in the D1 tree than in the D2 tree (Fig. 3a). Thus, on DOY 238, one day after irrigation, the value of $\Psi_{p d}$ in the D1 tree was significantly greater than on the previous day $(P<0.0001)$, while in the D2 


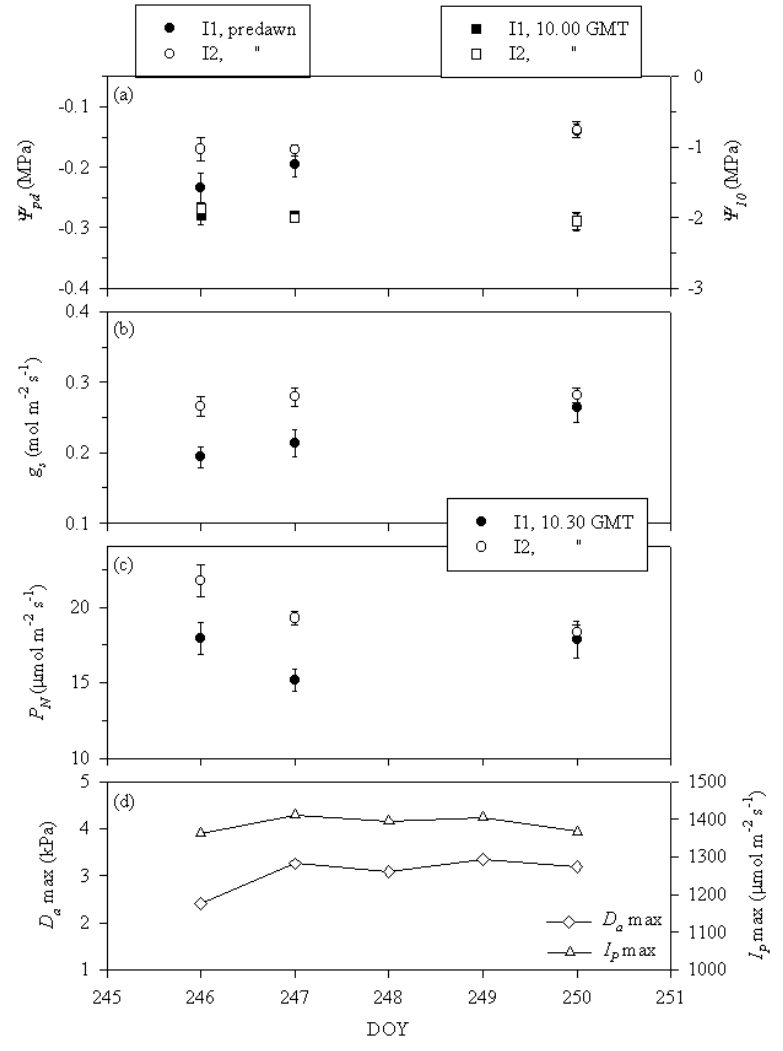

Figure 4. Leaf water status and gas exchange measurements measured in current year leaves of the I trees before and during the drip versus pond irrigation experiment. Figure 4 a shows the values of leaf water potential at predawn $\left(\Psi_{p d}\right)$ and at $10.00 \mathrm{GMT}\left(\Psi_{10}\right)$; each point represents the average of six values. Figure $4 \mathrm{~b}$ and $4 \mathrm{c}$ show the values of stomatal conductance to $\mathrm{H}_{2} \mathrm{O}\left(g_{s}\right)$ and net photosynthesis $\left(P_{N}\right)$, respectively, measured at $10.30 \mathrm{GMT}$; each point represents the average of 10 values. Vertical bars indicate twice the standard error. The I1 tree was pond irrigated, while the I 2 tree was drip irrigated. Further details on both treatments are given in the text. Figure $4 d$ shows the daily maximum values of vapour pressure deficit of the air $\left(D_{a} \max \right)$ and photon flux density $\left(I_{P} \max \right)$ recorded on the measurement days. DOY $=$ day of year. GMT $=$ Greenwich Mean Time.

tree about the same $\Psi_{p d}$ value was recorded on both days. The maximum $\Psi_{p d}$ value, observed on DOY 240 , was $-0.32 \mathrm{MPa}$ for the D1 tree and $-0.49 \mathrm{MPa}$ for the D2 tree. At the end of the experimental period, on DOY 243, the recorded values were $-0.44 \mathrm{MPa}$ for the D1 tree and $-0.69 \mathrm{MPa}$ for the D2 tree. The error bars shown in Figure 3 a indicate that the differences between treatments after rewatering were significant on all the measuring days. The $\Psi_{10}$ values shown in the same figure, although more variable due to the changing weather conditions (Fig. 3d), show that at the end of the experiment, on DOY 243, the D1 tree was less stressed than the D2 tree. No significant differences, either in $\Psi_{p d}$ or in $\Psi_{10}$, were recorded between the I1 and I 2 trees during the drip versus pond irrigation experiment (Fig. 4a).

Figure $3 \mathrm{~b}$ shows that before irrigating on DOY 237, the average value of $g_{s}$ measured at 10.30 GMT in the D1 tree $\left(0.12 \mathrm{~mol} \cdot \mathrm{m}^{-2} \cdot \mathrm{s}^{-1}\right)$ was significantly lower $(P<0.006)$ than that of the D2 tree $\left(0.17 \mathrm{~mol} \cdot \mathrm{m}^{-2} \cdot \mathrm{s}^{-1}\right)$. The values of $g_{s}$ in both trees increased quickly during the drip versus pond irrigation experiment. In fact, the average values of $g_{s}$ just one day after irrigation were 0.22 and $0.26 \mathrm{~mol} \cdot \mathrm{m}^{-2} \cdot \mathrm{s}^{-1}$ for the D1 and D2 trees, respectively. After DOY 238 no significant differences in $g_{s}$ between the D1 and D2 trees were observed. Perhaps the high values of $g_{s}$ recorded after rewatering were not only due to the water supplied, but also to the decrease in the atmospheric demand (Fig. 3d), which probably reduced stomatal closure. The I 2 tree showed about the same $g_{s}$ values throughout the experiment (Fig. 4b). This was expected, since the irrigation practice carried out on this tree during the drip versus pond irrigation experiment was the same as that applied since the beginning of the dry season, as explained in the "Irrigation experiments" section. Prior to pond irrigating the I1 tree, the average $g_{s}$ value measured in this tree $\left(0.19 \mathrm{~mol} \cdot \mathrm{m}^{-2} \cdot \mathrm{s}^{-1}\right)$ was significantly lower $(P<0.002)$ than that of the I2 tree $\left(0.27 \mathrm{~mol} \cdot \mathrm{m}^{-2} \cdot \mathrm{s}^{-1}\right)$. No differences in $g_{s}$ between the I1 and I2 trees were observed at the end of the experimental period.

As with $g_{s}$, the differences in $P_{N}$ between the D1 and D2 trees (Fig. 3c), and also between the I1 and I2 trees (Fig. 4c), decreased after irrigation, indicating that $P_{N}$ increased more in the pond-irrigated than in the drip-irrigated trees. In the D trees, $g_{s}$ increased markedly from DOY 237 to DOY 238 (Fig. 3b), while $P_{N}$ decreased (Fig. 3c). This apparent discrepancy is explained by the weather conditions recorded on both days. Day of year 237 was a bright day without clouds and with a relatively high atmospheric demand. Day of year 238, however, was partially cloudy, with a low atmospheric demand. At about 10.30 GMT, when the values of $g_{s}$ and $P_{N}$ were measured, the average values of incident photon flux density $\left(I_{P}\right)$ were $1218 \mu \mathrm{mol} \cdot \mathrm{m}^{-2} \cdot \mathrm{s}^{-1}$ on DOY 237 and $345 \mu \mathrm{mol} \cdot \mathrm{m}^{-2} \cdot \mathrm{s}^{-1}$ on DOY 238 . At that time of the day, the values of vapour pressure deficit of the air $\left(D_{a}\right)$ were on average $2.8 \mathrm{kPa}$ on DOY 237 and $0.8 \mathrm{kPa}$ on DOY 238. Thus, on the one hand the low $I_{P}$ on DOY 238 was responsible for the low values of $P_{N}$. For the 'Manzanilla' variety, Díaz-Espejo [8] found that light saturation for $P_{N}$ occurs when $I_{P} \geq 1600 \mu \mathrm{mol} \cdot \mathrm{m}^{-2} \cdot \mathrm{s}^{-1}$. On the other hand, the low $D_{a}$ of DOY 238 allowed the plant to keep the stomata open, which explains the high values of $g_{s}$ recorded on that day. In previous experiments carried out in a nearby orchard with trees of similar characteristics to those of our experimental orchard, Fernández et al. [16] found a proportional decrease in $g_{s}$ with increasing $D_{a}$, for $D_{a}$ values of up to approximately $3.5 \mathrm{kPa}$.

\section{DISCUSSION}

We were only able to instrument two pairs of D and I trees, due to our limited number of sensors for recording sap flows. Despite the lack of replications, the same trend on relative $E_{p}$ was registered in the two pairs of experimental trees, which made us trust the results. The fact that the daily transpiration of the pond-irrigated trees increased substantially more than that of the drip-irrigated trees (Fig. 2) indicates that the transpiration of the trees in which just a part of the rootzone was affected by irrigation was curtailed. The time course of atmospheric demand, illustrated by the $E T_{o}$ values shown in the figure, does not seem to be responsible for the changes in the relative $E_{p}$ values. The water contents in the soil volumes affected by 
irrigation were similar for all the experimental trees, and close to field capacity (Tab. II). We assume that, even in the case of the D1 and D2 trees where the greatest differences in $\theta$ were observed, they did not have any significant influence on the relative $E_{p}$ values. Actually, $\theta$ values for both trees were the same in the top metre of soil, where the greatest part of the root system grows [13]. Therefore, the differences in relative transpiration between the pond-irrigated and the drip-irrigated tree, for both pairs of trees, seem to be due to the amount of the rootzone wetted by irrigation. Bongi and Palliotti [3], in a splitroot experiment, divided the root system of young 'Frantoio' olive plants into two parts. The biggest part was irrigated at $-0.2 \mathrm{MPa}$ soil potential $\left(\Psi_{\text {soil }}\right)$, while the smallest part was maintained at $-1.1 \mathrm{MPa}$. Lower stomatal conductance and growth were observed in these plants than in similar plants with both split roots irrigated at $\Psi_{\text {soil }}=-0.2 \mathrm{MPa}$. The authors speculated about the idea of a signal originated in the roots, similar to what Zhang and Davies [34] observed in maize. Comprehensive reviews on the role of abscisic acid (ABA), ethylene and other molecules in the capacity of the roots for sensing soil conditions and signalling these to the shoots have recently been published $[2,24]$. Rather than the effect of a single signal, the results obtained by Bongi and Palliotti [3], and those shown here, may be due to a complex process. As Tardieu and Davies [32] stated, "Stomatal conductance, leaf and root water potential, water flux, and xylem [ABA] have multiple interrelations which cannot be summarised by a relationship between any of these variables". Hydraulic control of stomata closure had been reported mainly in woody species such as Douglas fir [19] and Betula occidentalis [29]. However, it has recently been reported in semi-woody species such as Hymenoclea salsola [5], and in the herbaceous bell pepper plant [33]. Fuchs and Livingston [19] interpreted the difference in stomatal response to root pressurisation between woody and herbaceous plants on the basis that the usually larger woody plants are less reliant on relatively slow-moving root signals for short-term stomatal control. The hydraulic signal is a simple and rapid form of root-to-shoot communication that can initiate stomatal responses or other leaf-level changes. Schulze [30] suggested that large woody species would lack a chemical root signal, because the long transport time would make root-signalling ineffective for short-term stomatal regulation. Hubbard et al. [22] showed that, under controlled conditions where steady-state flow was promoted, $g_{s}$ and $P_{N}$ in ponderosa pine were responsive to changes in the hydraulic conductance of the soil to the leaf pathway. In their study, they roled out any involvement of a root signal in response to changes in the hydraulic conductance; first, because the plants were well-watered throughout the experiment and, second, because the changes in the hydraulic conductance were induced dowstream from the roots. We have not investigated the nature of any signal acting between the roots and the shoots, but the results shown in Figure 2 indicate that when part of the root system of mature 'Manzanilla' olive trees growing under field conditions is left in drying soil the transpiration of the trees is curtailed. This can probably be extrapolated to other types of localised irrigation systems, apart from the drip irrigation used in our orchard. This does not necessarily mean that localised irrigation systems are not appropriate for irrigating olive or other fruit tree orchards. In fact, the plants' stress signalling system is being currently used in agriculture to increase the water use efficiency of some crops. This is the case for the partial root drying approach - PRD irrigation - on grapevine and tomato $[6,31]$. We have to point out, however, that the conditions of our drip versus pond irrigation experiment differ from those of the PRD approach, since one of the key feactures of PRD is that the wetted and drying sides of the irrigation system must be alternated on a 10-14 day cycle [7]. The fact that the amount of the root zone wetted by irrigation influences water losses by transpiration should be taken into account by the users of equation (1), in the sense that the soil volume affected by irrigation must be considered before assuming than a $K_{c}$ value taken from the literature is appropriate for the orchard.

After rewatering during the drip versus pond irrigation experiment, the recovery of water status and gas exchange of the leaves was greater and quicker in the pond-irrigated D1 tree than in the drip-irrigated D2 tree. This agrees with the results on relative transpiration discussed above, supporting the hypothesis that a drip irrigation system which supplies water to only a part of the root system limits water consumption of 'Manzanilla' olive trees. Results from previous experiments indicate that both $\Psi_{p d}$ and $\Psi_{10}$ in stressed olive trees recover quickly after rewatering, and that the values of $g_{s}$ and $P_{N}$ recover more slowly, the delay depending on the level of water stress previously reached $[11,16,27]$. Our results show that $g_{s}$ and $P_{N}$ increased quickly in the D trees after rewatering, reaching similar values to those of the I trees just a couple of days after applying water for the first time (Figs. 3 and 4). This quick recovery was probably due to the fact that the degree of water stress reached by the $\mathrm{D}$ trees before rewatering was not too severe (Fig. 3a). The unusually high rainfall of the hydrological year 1997-98, 717.2 $\mathrm{mm}$, led to average $\theta$ values on DOY 231 of $0.17 \mathrm{~m}^{3} \cdot \mathrm{m}^{-3}$ in the $1-2 \mathrm{~m}$ deep soil layer, in both the D1 and D2 trees. These values are greater than those recorded in the orchard at the end of the dry season on years of average rainfall [25]. Maximum values of $\Psi_{p d}$ were recorded on the $\mathrm{D}$ trees two days after rewatering. These values remained below $-0.3 \mathrm{MPa}$, while the $\Psi_{p d}$ values recorded in the I trees were close to $-0.2 \mathrm{MPa}$. Even so, the $\Psi_{p d}$ values of the $\mathrm{D}$ trees after rewatering were well above $-0.5 \mathrm{MPa}$, considered as a threshold for water deficit in olive [16], as well as in other species $[4,10]$. In fact, $\Psi_{p d}$ is closely related to the soil water content, and it is generally accepted that $\Psi_{p d}$ can be used as an indicator of water stress in fruit trees. Although there are limitations to this assumption [1], the work by Natali et al. [27] and Fernández et al. [16], among others, shows that the value of $\Psi_{p d}$ can be used as an indicator of the degree of water recovery of the olive tree at night. Although $\Psi_{10}$ depends greatly on the atmospheric conditions, the values of $\Psi_{10}$ recorded in the $\mathrm{D}$ trees also recovered substantially after rewatering.

\section{CONCLUSIONS}

Drip irrigation in which a part of the root system is left in drying soil limits transpiration in 'Manzanilla' olive trees. This may apply to any other type of localised irrigation system supplying water to a part of the rootzone only. This may be due to stomatal closure induced by roots left in dry soil, although this 
point has not been investigated in this work. This does not necessarily mean that localised irrigation systems are not appropriate for irrigating olive or other fruit tree orchards. On the one hand, a reduction in transpiration could increase the water use efficiency in the orchard. On the other hand, any reduction in transpiration could lead to a decrease in crop performance. This, and the nature of the signal or signals involved in the olive's stress signalling system could be the topics for pioneering lines of research. In unirrigated olive trees, the recovery after the dry season of both leaf water potential and gas exchange was greater and quicker with pond irrigation than with drip irrigation.

Acknowledgements: The authors thank the Comisión Interministerial de Ciencia y Tecnología of the Spanish Ministry of Education and Science for the financial support of this project. Thanks are also due to B.E. Robinson and M.B. Kirkham, for their valuable advice on the first draft of this paper. The authors also express their appreciation to the staff of the experimental farm $\mathrm{La}$ Hampa for their help with the experimental work.

\section{REFERENCES}

[1] Améglio T., Archer P., Cohen M., Valancogne C., Daudet F.A., Dayau S., Cruiziat P., Significance and limits in the use of predawn leaf water potential for tree irrigation, Plant and Soil 207 (1999) $155-167$.

[2] Bingham I.J., Soil-root-canopy interactions, Ann. Appl. Biol. 138 (2001) 243-251.

[3] Bongi G., Palliotti A., Olive, in: Schaffer B., Andersen P.C. (Eds.), Handbook of Environmental Physiology of Fruit crops. Volume I: Temperate Crops, CRC Press, Inc., 1994, pp. 165-187.

[4] Bréda N., Granier A., Barataud F., Moyne C., Soil water dynamics in an oak stand, Plant and Soil 172 (1995) 17-27.

[5] Comstock J., Mencuccini M., Control of stomatal conductance by leaf water potential in Hymenoclea salsola (T. \& G.), a desert subshurb, Plant Cell Environ. 21 (1998) 1029-1038.

[6] Davies W.J., Bacon M.A., Thompson D.S., Sobeih W., GonzálezRodríguez L., Regulation of leaf and fruit growth in plants growing in drying soil: exploitation of the plants' chemical signalling system and hydraulic architecture to increase the efficiency of water use in agriculture, J. Exp. Bot. 51 (2000) 16171626.

[7] Davies W.J., Wilkinson S., Loveys B., Stomatal control by chemical signalling and the exploitation of this mechanism to increase water use efficiency in agriculture (Research review), New Phytol. 153 (2002) 449-460.

[8] Díaz-Espejo A., Modelización del intercambio gaseoso en el olivo: aplicación a la optimación del riego, Ph.D. Thesis, Department of Plant Biology and Ecology, University of Seville, 2000.

[9] Doorenbos J., Pruitt W.O., Guidelines for predicting crop water requirements, FAO Irrigation and Drainage Paper No. 24, 2nd ed., FAO, Rome, 1977.

[10] Elfving D.C., Kaufmann M.R., Hall A.E., Interpreting leaf water potential measurements with a model of the soil-plant-atmosphere continuum, Physiol. Plant. 27 (1972) 161-168.

[11] Fereres E., Ruz C., Castro J., Gómez J.A., Pastor M., Recuperación del olivo después de una sequía extrema, Proceedings of the XIV Congreso Nacional de Riegos, Aguadulce (Almería), 11-13 June, 1996, pp. 89-93.

[12] Fernández J.E., Moreno F., Water use by the olive tree, J. Crop Prod. 2 (1999) 101-162.

[13] Fernández J.E., Moreno F., Cabrera F., Arrúe J.L., Martín-Aranda J., Drip irrigation, soil characteristics and the root distribution and root activity of olive trees, Plant and Soil 133 (1991) 239-251.

[14] Fernández J.E., Moreno F., Martín-Aranda J., Fereres E., Olivetree root dynamics under different soil water regimes, Agric. Mediterr. 122 (1992) 225-235.
[15] Fernández J.E., Moreno F., Clothier B.E., Green S.R., Aplicación de la técnica de compensación de pulso de calor a la medida del flujo de savia en olivo, Proceedings of the XIV Congreso Nacional de Riego. Aguadulce (Almería), 11-13 June, 1996, pp. 1-7.

[16] Fernández J.E., Moreno F., Girón I.F., Blázquez O.M., Stomatal control of water use in olive tree leaves, Plant and Soil 190 (1997) 179-192.

[17] Fernández J.E., Palomo M.J., Díaz-Espejo A., Clothier B.E. Green S.R., Girón I.F., Heat-pulse measurement of sap flow in olives: tests, root flow and diagnostics of water stress, Agric. Water Manage. 51 (2001) 99-123.

[18] Fernández J.E., Moreno F., Murillo J.M., Cuevas M.V., Kohler F., Evaluating the effectiveness of a hydrophobic polymer for conserving water and reducing weed infection in a sandy loam soil, Agric. Water Manage. 51 (2001) 29-51.

[19] Fuchs E.E., Livingston N.J., Hydraulic control of stomatal conductance in Douglas fir [Pesudotsuga menziesii (Mirb.) Franco] and alder [Alnus rubra (Bong)] seedlings, Plant Cell Environ. 19 (1996) 1091-1098.

[20] Girona J., Strategia di deficit irriguo controllato nell'olivo, Book of Proceedings of the Corso internazionale di aggiornamento tecnico scientifico "Gestione dell' acqua e del territorio per un olivicoltura sostenibile", COI-SeSIRCA-ISPAIM, Napoli, 24-28 September (2001), pp. 138-148.

[21] Green S.R., Clothier B.E., Water use of kiwifruit vines and apple trees by the heat-pulse technique, J. Exp. Bot. 39 (1988) 115-123.

[22] Hubbard R.M., Ryan M.G., Stiller V., Sperry J.S., Stomatal conductance and photosynthesis vary linearly with plant hydraulic conductance in ponderosa pine, Plant Cell Environ. 24 (2001) 113-121.

[23] Mantovani C.E., Berengena J., Villalobos F.J., Orgaz F., Fereres E., Medidas y estimaciones de la evapotranspiración real del trigo de regadío en Córdoba, Actas IX Jornadas Técnicas de Riego, Granada, 1991.

[24] Meinzer F.C., Clearwater M.J., Goldstein G., Water transport in trees: current perspectives, new insights and some controversies, Environ. Exp. Bot. 45 (2001) 239-262.

[25] Moreno F., Vachaud G., Martín-Aranda J., Vauclin M., Fernández J.E., Balance hídrico de un olivar con riego gota a gota. Resultados de cuatro años de experiencias, Agronomie 8 (1988) 521-537.

[26] Moreno F., Fernández J.E., Clothier B.E., Green S.R., Transpiration and root water uptake by olive trees, Plant and Soil 184 (1996) 85-96.

[27] Natali S., Xiloyannis C., Angelini P., Water consumptive use of olive trees (Olea europaea) and effect of water stress on leaf water potential and diffusive resistance, Acta Hortic. 171 (1985) 341-351.

[28] Palomo M.J., Aplicación del método de compensación de pulso de calor para medir flujo de savia en olivo, Ph.D. Thesis, Department of Agronomy, University of Córdoba, Spain, 2000.

[29] Saliendra N.Z., Sperry J.S., Comstock J.P., Influence of leaf water status on stomatal response to humidity, hydraulic conductance, and soil drought in Betula occidentalis, Planta 196 (1995) 357366.

[30] Schulze E.D., Water and nutrient intractions with plant water stress, in: Mooney H.A., Winner W.E., Pell E.J. (Eds.), Response of plants to multiple stress, Academic Press, New York, 1991, pp. 89-103.

[31] Stoll M., Loveys B., Dry P., Improving water use efficiency of irrigated horticultural crops, J. Exp. Bot. 51 (2000) 1627-1634.

[32] Tardieu F., Davies W.J., Integration of hydraulic and chemical signalling in the control of stomatal conductance and water status of droughted plants, Plant Cell Environ. 16 (1993) 341-349.

[33] Yao C., Moreshet S., Aloni B., Water relations and hydraulic control of stomatal behaviour in bell pepper plant in partial soil drying, Plant Cell Environ. 24 (2001) 227-235.

[34] Zhang J., Davies W.J., Abscisic acid produced in dehydrating roots may enable the plant to measure the water status of the soil, Plant Cell Environ. 12 (1989) 73-81. 